\title{
Causal Inference
}

The 
Scott

Cunningham

CITMT 


\section{Causal Inference}

\section{The \\ Mixtape}

Yale

UNIVERSITY

NEW HAVEN

PRESS

$\&$ LONDON 
Copyright $@ 2021$ by Scott Cunningham.

All rights reserved.

This book may not be reproduced, in whole or in part, including illustrations, in any form (beyond that copying permitted by Sections 107 and 108 of the U.S. Copyright Law and except by reviewers for the public press), without written permission from the publishers.

Yale University Press books may be purchased in quantity for educational, business, or promotional use. For information, please e-mail sales.press@yale.edu (U.S. office) or sales@yaleup.co.uk (U.K. office).

Set in Roboto type by Newgen.

Title-page illustration: iStock.com/2p2play.

Printed in the United States of America.

Library of Congress Control Number: 2020939011

ISBN 978-0-300-25168-5 (pbk. : alk. paper).

A catalogue record for this book is available from the British Library.

This paper meets the requirements of ANSI/NISO Z39.48-1992 (Permanence of Paper). 
To my son, Miles, one of my favorite people.

I love you. You've tagged my head and heart. 
This page intentionally left blank 